\title{
Recap: Forecasting the 2012 Election
}

James E. Campbell, guest editor, University at Buffalo, SUNY

The October 2012 issue of PS published a symposium of presidential and congressional forecasts made in the months leading up to the election. In the following articles, the forecasters assess the accuracy of their models.

A month after Election Day and well after the postmortems had been written, vote counting continues. The national two-party popular vote percentage for President Obama used in these postmortems was updated to $51.8 \%$. As the issue goes to press the two-party vote share for President Obama now stands at $51.9 \%$.

Editor's Note: A typographical error in the October 2012 issue of $P S$ forecasting symposium's summary table of the forecasts (PS: Political Science and Politics 45 (4): 612) stated that Klarner predicted Obama would receive $51.2 \%$ of the twoparty popular vote. His prediction was that Obama would receive $51.3 \%$.

We regret the error.

\section{PRIMARY MODEL GETS IT RIGHT AND EARLY}

\section{Helmut Norpoth, Stony Brook University}

Michael Bednarczuk, University of Wisconsin, Milwaukee

In January of 2012, the Primary Model predicted that Barack Obama would defeat Mitt Romney by a comfortable margin. He did. Obama's popular vote total topped Romney's by more than four million votes. The Primary Model's forecast was by far the earliest of those assembled in the special 2012 PS symposium (45 (4): 614-617). Even so it predicted an Obama victory with greater certainty (almost 90\%) than any other one. To put this performance in perspective, note that several models got it wrong in 2012, and hardly any of the other ones picking Obama to win did so with much certainty. Many preelection polls also failed to predict an Obama victory with their final estimate, including the venerable Gallup Poll. How did the Primary Model get it right so far in advance of Election Day 2012?

Recall that the model relies on primary elections as well as an electoral cycle. The cycle captures the historical fact that the presidential party more often wins than loses reelection after one term in office. Whenever one party wrests control of the White House from the other it can count on holding on to it for two terms, after which the odds even out. In that sense Obama had history on his side in 2012, like Ronald Reagan in 1984, and
Bill Clinton in 1996, to cite a few recent cases. The American electorate is inclined to give first-term presidents the benefit of the doubt to make good on promises of change that brought them to office. There is no better proof of that attitude in 2012 than findings from the exit poll about how voters weighed the economy for the vote choices. Although voters expressed much dissatisfaction with the overall economy and their own financial situation, Barack Obama got less blame for the current economic problems than did his predecessor George W. Bush.

Besides history, a strong performance in primaries also predicted Obama's reelection. As we have shown, no primary has a better record of predicting the outcome of the general election for president since 1952 than the New Hampshire primary. So this effect could be spotted very early in the election year. Obama was indeed on the ballot in that primary in 2012, and won in commanding fashion against a field of unknown candidates. This was a clear signal that Obama's renomination would go uncontested. Presidents who face a challenge to renomination rarely, if ever, go on to win reelection. Jimmy Carter's defeat in the 1980 election, following the Kennedy challenge for renomination, comes to mind. Obama's solid support in Democratic ranks on Election Day was confirmed by the exit poll finding that more than $90 \%$ of self-identified Democrats voted for Obama, with $45 \%$ of Independents doing so as well. While Romney's victory in his party's primary in New Hampshire made him the strongest possible Republican nominee, his win was not enough to trump the advantage that Obama, as the incumbent-party candidate, got from being unchallenged in primaries. Unfortunately for Romney as any out-party candidate, the Primary Model assigns far greater weight to the in-party candidate for predicting the outcome of the general election.

\section{ELECTION FORECAST: A LOOK BACK AT THE \\ TIME FOR CHANGE MODEL AND THE 2012 PRESIDENTIAL ELECTION}

\section{Alan I. Abramowitz, Emory University}

The Time for Change Model once again correctly predicted the winner of the US presidential election. In late August, before the Republican and Democratic national conventions, the model predicted that President Obama would win $50.6 \%$ of the major party vote to $49.4 \%$ for his Republican challenger, Mitt Romney. When all the votes are counted, it now appears that Obama will end up with approximately $51.8 \%$ of the vote, making the 